The University of San Francisco

USF Scholarship: a digital repository @ Gleeson Library |

Geschke Center

Sport Management

College of Arts and Sciences

2016

\title{
Building the Brightrock Brand through Change
}

Michael M. Goldman

University of San Francisco, mmgoldman@usfca.edu

Mignon Reyneke

Tendai Mhizha

Follow this and additional works at: http://repository.usfca.edu/sm

Part of the Business Commons

\section{Recommended Citation}

Michael M. Goldman, Mignon Reyneke, Tendai Mhizha, (2016) "Building the BrightRock brand through change", Emerald Emerging Markets Case Studies, Vol. 6 Issue: 3, pp.1-23, https://doi.org/10.1108/EEMCS-05-2016-0070

This Article is brought to you for free and open access by the College of Arts and Sciences at USF Scholarship: a digital repository @ Gleeson Library | Geschke Center. It has been accepted for inclusion in Sport Management by an authorized administrator of USF Scholarship: a digital repository @

Gleeson Library | Geschke Center. For more information, please contact repository@usfca.edu. 


\section{Building the BrightRock brand through change}

A typical Johannesburg afternoon thunderstorm rolled in over the economic capital of South Africa on a hot summer's day in early January 2015. Suzanne Stevens, the Executive Director of Marketing for BrightRock, was enjoying a well-deserved vacation after helping steer the life insurance business through its first three years of operation. Although BrightRock had quickly established itself as an innovative and growing competitor in the local market, Stevens knew that the next three years would further test their business model and senior team. By designing the world's first needs-matched life insurance product, as opposed to the existing model, which aggregated various insurance needs into uniform blocks of lump-sum cover, BrightRock had begun to disrupt the industry's accepted practice.

As Stevens saw the first lightning strike on the horizon, she wondered whether BrightRock brand's awareness and differentiation among their channel and target market were strong enough. Having built a brand positioned as the antithesis to what consumers perceived to be the "greedy, disingenuous, and opaque financial services" that characterized the 2008 global financial crisis, Stevens wondered how she could build more positive associations, and a more competitive industry positioning, by using their existing Change Exchange online platform. A career-change moment campaign launched during the FIFA World Cup in Brazil in mid-2014 had worked well for the brand, which suggested that Stevens' content-driven marketing strategy could be expanded to other change moments and additional media platforms. BrightRock's product was enjoying growing uptake within their existing broker channel, while revenues from customers across the country were growing within budget expectations. Stevens was worried however about how sustainable BrightRock's competitive advantage would prove to be. As social media and online content platforms increased in popularity, especially on mobile devices, she wondered how her marketing and media choices needed to adapt. She was conscious that in time, other life insurance competitors would potentially be able to replicate BrightRock's product offering by building a comparable system, and wondered how to strengthen her brand relative to the dominant traditional firms in the industry.

\section{Life insurance in South Africa}

The South African insurance market was regarded as the most developed in Africa, accounting for $71 \%$ of Africa's total premiums and achieving the third-highest insurance penetration $(15.3 \%)^{1}$. The life insurance segment had achieved growth of $14.9 \%$ CAGR in the previous four years, including $\$ 51.2 \mathrm{bn}$ total gross written premiums in $2014^{2}$. Analysts highlighted the high crime rates in the country and the prevalence of HIV as contributors to the awareness of the benefits of life insurance ${ }^{3}$. Old Mutual Life Assurance Company had the largest market share by value, of $14.8 \%$, by the end of 2014, followed by Sanlam Life Insurance Limited, MMI Holdings, and Liberty Group Limited. With the leading players seen as homogenous, and insurance regarded as a commodity, competition was based on lower cost structures, greater efficiencies, and better customer service. The market was forecast to grow at $10.8 \%$ CAGR during the five years till 2019, partly due to rising incomes and purchasing power of the growing middle class, the rollout of a national health insurance scheme, increased life expectancy, and more South Africans being lifted out of poverty (see exhibit 1). Some analysts also pointed to a R9.3 trillion gap between the amount of insurance needed by South Africa's 13 million regular income earners (18-65) to maintain their households' standards of living, and the actual extent of life insurance ${ }^{4}$. The richest $20 \%$ of South Africans (average age 42, annual after tax earnings of greater than R148,718) typically required life cover of about R3.6m, leaving an insurance gap of almost R1.9m, whereas the poorest 20\% (average age 37, annual after tax earnings of less than R18,034) typically required life cover of R54,131, leaving an insurance gap of R50,453. 
An industry competitiveness analysis suggested that the degree of rivalry within the market was strong, with moderate buyer power and threat of new entrants, and strong supplier power $^{5}$. In terms of buyer power, the many individual customers were in a weaker situation than large corporate clients. There was a lack of customer loyalty and an increase in online comparison sites and because there are no penalties or loss of value, switching was fairly inexpensive. Supplier power was judged to be strong due to the limited number of ICT manufacturers and specialized software houses.

This analysis pointed to a moderate likelihood of new entrants to the South African life insurance market. Highly specialized expertise and knowledge, access to distribution networks, and substantial capital, were seen as requirements to launch a successful operation, while the leading incumbents enjoyed strong reputation and customer recognition. These market leaders had been losing their traditional share of new business to smaller niche players however, with a shift towards a direct business model. One of the new competitors, Frank.net, conducted a focus group with under-40s and found that $70 \%$ suggested strongly that they would use the Internet to purchase life insurance. The Frank.net CEO, Lenerd Louw, believed that success in the direct life insurance industry required two ingredients:

"A sophisticated and real-time technology platform that enables the simple, convenient and transparent product offering to be sold quickly and efficiently... [and] the right brand and advertising message, placed in the right medium... to convert interest into real sales.”

A PricewaterhouseCoopers industry survey identified the financial soundness and stability of the insurance market, the highly competitive and innovative marketplace, and the simultaneous established and emerging nature of the market, as strengths. Weaknesses included a perceived shortage of information technology and actuarial skills, an aging broker network, and a large number of legacy products ${ }^{7}$.

\section{Establishing BrightRock}

In June 2010 Schalk Malan, a Fellow of the Faculty of Actuaries with almost a decade's experience in the development, implementation, maintenance and marketing of insurance products, had noticed a gap in the very competitive market of life insurance. Malan discussed this gap with a former colleague, Sean Hanlon, who had identified similar issues in the industry. Malan found that none of the established players in the life insurance industry in South Africa had a product that was tailored exactly to the client's needs or a product that was flexible to change as the client moved through changes in his/her life. Traditional life insurance was sold in terms of the total cover value and monthly premium that the customer could afford, which was decoupled from the underlying need the customer wished to cover. In this way, existing products were structured around the events that triggered a claims payout, death, disability or dread disease, rather than around the financial consequences customers would face as a result of the claims event. Hanlon was immediately keen to develop the idea further. At the time, Hanlon was with the Discovery Group after helping them launch Discovery Life and set up the Group's own distribution force. Malan and Hanlon partnered with two more former colleagues, Leopold Malan (former Chief Information Officer at Discovery Health) and Suzanne Stevens (former General Manager of Marketing at the Discovery Group) to create the founding team of BrightRock (Proprietary) Limited. 
The Lombard Insurance Group, headed by Miles Japhet a respected life insurance entrepreneur in his own right, had a 20-year track record in the market and set BrightRock up as an underwriting management agency of Lombard Life, thereby providing BrightRock access to an existing life insurance license. The partnership with Lombard Insurance Group allowed BrightRock the opportunity to have a financially sound business partner with the capital to fund their initial business expenses, and was based on their mutual values and a shared passion for entrepreneurial enterprise and the insurance industry. BrightRock's initial primary reinsurance partner was Hannover Re, providing the necessary funding of the risk book. Since May 2013, the company's primary reinsurance treaty has been with Munich Re, the world's largest reinsurer.

BrightRock's structure did not include a CEO or Managing Director. Each of the four founders become Executive Directors, with clearly defined areas of accountability and responsibility, and worked together to lead the business. Schalk Malan headed the Actuarial side of the business. Hanlon had 23 years' experience in life insurance with major South African and offshore insurance companies and took on the role of Executive Director of Sales and Distribution. Leopold Malan, an IT consultant who had consulted for many of the major South African banks before heading up Systems for Discovery's local and offshore health operations, took the role of Executive Director: Processing. Suzanne Stevens, a Chartered Marketer with a wealth of experience in marketing and communications took the role of Executive Director of Marketing.

\section{BrightRock’s marketing strategy}

BrightRock was launched on May $30^{\text {th }}, 2011$ at the popular and contemporary CIRCA Gallery in Johannesburg. One of the first tasks for Stevens was to provide a name for the company. In doing so, she had a couple of criteria: the name had to be "of this century", modern and tech sounding, but it also had to carry meaning. It had to be a name that was easy to pronounce (especially to second language English speakers), it had to be easy to spell and to Google, but it also had to be available in terms of URL's. With these criteria in mind, Suzanne came up with 4 or 5 options that she put forward to the founding team. BrightRock was the one they liked best as they felt that it spoke to the idea of optimism and the future in "bright", but also captured the ideas of strength, reliability, trustworthiness and longevity in "rock".

Prior to the official launch of the product in 2012, Suzanne set about completing the marketing strategy for BrightRock. As part of this she did a thorough analysis of the company's competitors and how they were positioned (see exhibit 2). Specifically she considered what competitors said about themselves and discovered the following:

- The South African life insurance industry had stagnated in terms of marketing and was almost entirely sales driven

- Most advertising in this sector was erratic, stale, and focused on the category rather than a specific product offering

- $\quad$ Price was the basis of competition

- Most insurers made use of insurance brokers for distribution, although direct life insurers were emerging quickly

- Consumer 'noting' of advertising in the insurance category was one of the lowest

- Most life insurance companies said the same thing (they're flexible, customer centric, they provide peace of mind, they have customized solutions) and all use the same terminology, thus making this for an extremely undifferentiated industry ${ }^{9}$. 
BrightRock based their marketing strategy development on the Reputation Institute's RepTrack $^{\circledR}$ model. The Reputation Institute, an international corporate reputation research and advisory firm, developed this reputation measurement model around the seven dimensions of products/services, innovation, workplace, governance, citizenship, leadership, and performance ${ }^{10}$. One stream of strategy development focused on reputation management, while a second stream of work developed the marketing tactics required to deliver on the strategy. Stevens recalled:

"We used the reputation driver model to guide our thinking, and then used our experience and a healthy dose of gut feel to guide the execution.”

Stevens identified all BrightRock's key stakeholders and ranked them based on their importance for the company's launch. She then identified which reputation drivers (and associated messages) needed to be communicated to which stakeholders. For the launch blueprint, Stevens focused her marketing efforts on the media, the launch event, potential consumers, the brokers in the distribution channel, internal marketing to employees, and communication related to the new business acquisition process such as the application forms, policy document, and quote dashboard (see exhibit 3). For example, for potential consumers, the reputation drivers of products/services and innovation were employed, with the following messages emphasized:

- Products/services

o You're only buying cover you need

o Your cover stays relevant

o Your premiums stay affordable

o You get certainty about claims

- Innovation

o Our product starts with you and changes with your needs over time - that's a first

\section{Developing and distributing the BrightRock product}

In developing the product, the BrightRock leadership team rejected the traditional industry product process, which was largely rooted in an industrial-era production line approach, Stevens described as:

"You get an actuary sitting in an office with an Excel spreadsheet and a whiteboard. He will design a product, open a hatch, and slide it through to the systems development team. Once the programming is done, they pass it on to the marketing team to put on a picture of a happy family dancing on the beach, before sliding it through to distribution to go and sell” (see exhibit 4).

BrightRock took a different approach, pulling together a multi-disciplinary team to collaborate with the product development actuaries on the product design. Furthermore, through its design, the product itself would enable consumers to work with their financial adviser to structure their own life insurance solution based on their specific needs. The BrightRock team believed that consumers experience change in the course of their lives such as getting married, having children, landing a new job, or buying a new home, and there was no life insurance product that was flexible enough to adapt with the consumer through the changes in their lives. The BrightRock product was also designed to reduce the wastage built into traditional products, where premiums increased annually higher than inflation without taking the underlying asset coverage requirement into account. 
The BrightRock team recognized that typical documentation for life insurance products was filled with jargon and complicated language, which most consumers did not fully understand. The customer's lack of understanding could lead to dissatisfaction at the payout stage. BrightRock believed strongly that creating a consumer-friendly interface, using language that related directly to clients' needs and that they therefore could understand, would counteract these issues. The South African National Treasury and Financial Services Board had recently published a set of Treating Customers Fairly (TCF) guidelines, which included the product design, marketing, advice, point-of-sale and after-sale stages. Stevens was upset that, because of this lack of understanding, some life insurance customers were purchasing cover they considered "cheap" in the short-term, but which would become "more and more unaffordable over time." As Stevens recalled:

"It was a case of: You're the little client, you don't understand how the product works, you don't understand how to structure it, and you don't understand what you need or how much of it you need.”

BrightRock's product was therefore designed to give customers an opportunity to sit and have a conversation with their financial advisor about their insurance needs as an equal partner (see exhibit 5).

Financial advisers were equipped with an electronic quoting system for BrightRock, which they could use to co-develop the life insurance product with the client. Stevens argued that the product allowed the customer to "own the conversation" as the financial needs discussed were based on the customer's current monthly household expenses, the ages and needs of any children until their financial independence, and any debts that needed servicing. The language in the marketing tools mirrored this. The quote could be generated by running over 25 million algorithms in the back-end, allowing the customer to know almost immediately exactly how much each portion of the insurance cost. The cover could then be adapted and customized to the customer's individual needs (see exhibit 6). Schalk Malan, BrightRock's Executive Director: Actuarial, had been quoted in the media stating:

"BrightRock covers the same insurance events as other policies, but maps this cover back to clients' underlying financial needs. Customers are able at the outset to make a wide range of choices about how their cover should grow and change, to stay relevant and in tune with their needs. Even when those choices have been made, it is easier for clients of BrightRock to make changes to their cover should their circumstances change. Because each plan is made to every client's specifications, it is unlikely that two clients would have exactly the same BrightRock policy.”

Competing life insurance offerings allowed some degree of customization, but in most cases customers could only choose from modular, pre-packaged products. BrightRock customers could add more cover later or reduce cover if required, could even move from one kind of cover to another over time, and unlike any competing product, choose at claim stage whether to be paid out in a lump sum or monthly income. The flexibility of this product therefore made it sustainable over the customer's entire lifetime, which was not always true of other products in the market. The individualized nature of the product created an opportunity to cut waste out of the insurance product allowing BrightRock’s customers to receive 30 - 40\% more cover for every Rand spent.

The BrightRock product was distributed through independent financial advisors, who typically sold a range of insurance products from a number of providers. Industry commentators suggested that $25 \%$ of the 40,000 life and investment brokers in South Africa were independent, 
with the rest operating as tied advisors ${ }^{11}$. Research estimated the annual income per advisor at R563,528, with the typical advisor being a White male, aged 48, who has been practicing as a financial advisor for 17 years $^{12}$. Hanlon and the leadership team were considering a number of additional distribution channels, including exclusive BrightRock tied advisors, outbound telephone sales, and online platforms.

\section{Communicating the brand}

BrightRock launched their life insurance product in mid-2012. The launch was supported by a six-month R10m national television, radio, and print advertising awareness campaign (see exhibit 7). On DStv, the local satellite network and platform, the campaign ran on M-Net, BBC Entertainment, National Geographic, Kyknet, Discovery World, and BBC Lifestyle (entertainment channels), eNews (an independent news channel), SuperSport 1, 2, 3, and 4 (sport channels). The radio campaign featured on Talk Radio 702 and SAFM (talk radio channels), and Jacaranda, Highveld, KFM, East Coast Radio, Algoa FM, OFM, and RSG (music \& entertainment stations). The print campaign ran in the Saturday Personal Finance section of the Independent newspapers, including the Argus, Pretoria News, Saturday Star, and Daily News. BrightRock's 'first-time-advertiser' status contributed to the good efficiency and effectiveness achieved (R19.3m worth of exposure to $2.2 \mathrm{~m}$ people). As a first time advertiser, BrightRock had received an additional 38\% added value from media owners. BrightRock also completed a successful cinema tactical activation related to the James Bond Skyfall movie, reaching a live audience of 2,260 people, 4,100 movie goers through foyer activations, and 159,000 via advertising in the movie complex. A YouTube clip of this activation had achieved more than 80,000 views by end of 2014, and the campaign was reported in many trade publications and blogs.

A further successful marketing initiative was the "you change our ad" campaign. In early 2013 BrightRock was airing an advert on Radio 702, a Johannesburg-based commercial radio station, about a father meeting his newborn son for the first time. In the advert, the father expressed the concerns: "What if he doesn't like rugby, what if he likes the clarinet, what if he starts painting his nails, or worse he forms a Spice Girls tribute band!” Although Stevens argued that the implicit message of the advert was that outdated attitudes should change, some listeners did not interpret the advertising copy in this positive way. Based on this feedback, Stevens invited listeners and Facebook followers to rewrite the script and to vote on the best script submitted. The initiative was also promoted through Radio, Facebook, Twitter, YouTube, SoundCloud and LinkedIn. Within four weeks, 80 scripts were submitted and hundreds of votes were received. The revised script initiative generated 83 minutes of radio interviews (valued at over R750,000) and resulted in "unprecedented" enquiries via the BrightRock call center and a peak weekly reach of 278,000 on Facebook. Brand strategist and industry commentator Andy Rice described the campaign as a "groundbreaking initiative." Jessica le Roux, whose script submission was recorded as the new advert said: "The chance to see how adverts are made behind the scenes was a wonderful opportunity for me. I am also so pleased to see a company responding to consumers and not just paying them lip service."13

Stevens' marketing team also focused on supporting the distribution network of independent advisors. A weekly BrightRock Bulletin newsletter was developed and launched by mid-2013, while a number of high-touch advisor training events were hosted throughout the year. Technical marketing tools were also developed and refined to support the advisor to explain the BrightRock offering. 
In September 2012, Stevens appointed a new Public Relations (PR) agency to strengthen BrightRock's use of media relations. Stevens focused on building deeper editorial relationships with a number of key consumer publications to encourage greater use of BrightRock expertise and comments in relevant articles about life changes. This approach had resulted in coverage in mainstream consumer publications such as Fair Lady, Men's Health, Destiny Magazine and YOU/Huisgenoot. Between October 2012 and mid-2013, BrightRock achieved 79 media mentions across print, broadcast and online, valued at over R2.6m. For the first two quarters of 2013, BrightRock received the highest level of editorial exposure in the life insurance category in South Africa, 50\% more than the second-placed competitor.

\section{The Change Exchange}

Stevens acknowledged that customization was an attribute that all competitors claimed, and therefore focused BrightRock's brand messaging on the attribute of change. She anchored the brand's marketing messages in a trademarked phrase, "needs-matched life insurance," and the key message that your cover stays relevant throughout your life, emphasizing the idea that your life insurance product changes when your financial needs change (when you experience moments of change in your life). In order to communicate the depth of the Change Moments message, Stevens looked beyond traditional media.

The initial idea was to develop a toolkit of different calculation tools (such as mortgage calculators) to assist consumers to navigate their financial needs. Stevens was concerned that competitors already provided these toolkits, that the tools could be cold and impersonal, and that they assumed that consumers made decisions rationally. She was conscious of recent work by Daniel Kahneman and others that pointed towards behaviours and decision-making that contradicted the strictly rational model. Change moments, such as getting married, buying a house, having children, or shifting careers, were often emotional episodes that required a stronger human connection. Studies had also shown that clients were more likely to buy some form of insurance at these times. The Change Exchange community was created to provide an emotional hook to trigger a deeper conversation with the prospective customer. Stevens recalled:

"We needed something that would address the emotional nature of change, the irrationality which is invariably involved in the choices we make in these moments, and a way to provide some kind of emotional compass to consumers, rather than just a purely financial one. We needed a space were consumers could get a sense of empathy within a self-directed experience, as opposed to a patriarchal hierarchy."

In February 2014, BrightRock therefore created the ChangeExchange community platform, where they were able to facilitate conversations around Change Moments with genuine insight and authority. The ChangeExchange platform acknowledged the human factor in decisionmaking and allowed consumers to share stories and experiences and advise and guide each other through the change journey. The long-term objective was to create a strategy where consumers would reach out to BrightRock in Change Moments in their lives, rather than BrightRock having to fetch consumers in the market.

In order to achieve this goal, Stevens collaborated with a diverse group of contributors and experts (called Change Agents, see exhibit 8), as well as an in-house team, to create content that could engage consumers. On the platform, the Change Agents' posts about navigating their Change Moments were supplemented by video clips, lifestyle features, live seminars and financial tools. As consumers interacted with the content, some began to post their own content, 
while the PR and social media amplification of the easy-to-leverage content continued to achieve over R2m of media value each quarter.

\section{Dave's Big Break}

In early 2014, Stevens saw an opportunity to leverage the national interest in the FIFA World Cup $2014^{\mathrm{TM}}$ in Brazil. Previous market research had identified sport as the largest interest area (followed by comedy) for BrightRock's target market. The concept of "Dave's Big Break" was based on Tom Stoppard's 1966 play "Rosencrantz and Guildenstern Are Dead," in which these two minor characters in Shakespeare's Hamlet voice their confusion at the progress of significantly tragic events occurring around them in Hamlet, but which they are humorously unaware of. For the BrightRock campaign, a comedian would play the role of a South African sports journalist travelling to Brazil to cover the world's biggest soccer event, but without getting access to any of the games. eNCA, a local 24-hour television news broadcaster, agreed to include a dedicated "crossing" to Dave in Brazil during each day's primetime sports news broadcast (for 30 days). Dave's humorous pre-recorded commentary, which was positioned as editorial rather than advertising material, focused on how he adapted to the many obstacles he experienced as an unofficial unaccredited sports reporter on the fringes of the tournament.

While the media ROI was significant at 1:5, including production costs, and the BrightRock brand was again positively associated with using humour to safely discuss Change Moments, the campaign came with a steep learning curve and logistically proved to be a hairraising experience. Stevens noted that filming took place every day in Brazil (5 hours ahead of South Africa), segments then had to be sent back to South Africa for final editing, and be ready for the evening news broadcast for 30 consecutive days. Stevens acknowledged that the BrightRock team should have worked harder on tighter briefs and scripting upfront, which would have helped to relieve some of the pressure on the creative team in Brazil, and would have helped to deliver a more sophisticated end product. The social media amplification could also have been better. In hindsight, Stevens believed that a different social media skills-set on the ground in Brazil and contracting upfront on social media interaction would have helped.

\section{Change for 2015?}

Stevens believed that the coming year would be critical to the growth of the BrightRock brand and business. Although consumers and financial advisors were taking note, so were the competitors. Schalk Malan had been invited to present the design and communication of the BrightRock product to the annual Financial Services Council Life Insurance Conference in Australia, which Stevens viewed as a welcome endorsement of BrightRock's focus on the consumer and innovation. Stevens wondered how their content driven strategy, that had worked well thus far, could be amplified in the consumer market - and whether it could replace the company's investment in traditional advertising platforms. Within its first year, the Change Exchange had hosted 50,000 sessions on the site, with over 11,000 conversations on social media flowing from the topics discussed. BrightRock had achieved an engagement rate of $53 \%$ on their online platforms, compared to the industry average of $45 \%$.

By the end of 2014, Stevens and her team had developed a Consumer Marketing Model to guide their marketing decisions (see exhibit 9). In order to achieve a high engagement ratio around their Change Moments, BrightRock employed a combination of owned, earned and bought media. Stevens needed to decide what proportion of her marketing budget to invest across these three types of media. The brand had benefited substantially from the initial television, radio, and print advertising campaign, and there were a number of similar opportunities on Stevens' 
desk. BrightRock's media agency had put together an appealing package of spots on traditional media platforms, including during broadcasts of the upcoming Cricket World Cup in Australia and New Zealand, and during the Super Rugby season that dominated the first half of 2015 in South Africa. Stevens was also considering a sponsorship of a sport lifestyle talk show on SuperSport 1 and a women's lifestyle magazine show on Afrikaans pay-tv channel KykNet as an extension of the Change Moments interviews on the ChangeExchange - both of which could provide strong content co-creation opportunities for the brand. As a brand dedicated to Change Moments, Stevens wondered whether BrightRock too needed to change as it entered 2015. 
Exhibit 1: Selected South African economy \& life insurance industry indicators

\begin{tabular}{|l|r|r|r|r|r|r|}
\hline & 2012 & 2013 & 2014 & 2015 & 2016 & 2017 \\
\hline Population size (million) & 52.3 & 53 & 53.3 & 54.9 & & \\
\hline Population 65+ (million) & 2.8 & 2.9 & 2.9 & 3.1 & 3.2 & 3.3 \\
\hline Annual GDP growth (\%) & 2.5 & 1.9 & 1.5 & 2 & 2.1 & 2.4 \\
\hline Life insurance market value (\$ billion) & 37 & 45 & 51 & 58 & 65 & 72 \\
\hline Life expectancy at birth (years) & 56.3 & 56.9 & 57.4 & 57.6 & 57.8 & 57.8 \\
\hline
\end{tabular}

Source: Adapted from MarketLine (2015), BMI (2015) \& World Bank (2015)

Exhibit 2: Competitor positioning analysis - early 2011

\begin{tabular}{|l|l|l|}
\hline & Positioning & Payoff line \\
\hline Old Mutual & 166 Year heritage - always around & Do great things \\
\hline Liberty & Lifestyle partner - you have made it & Own your life \\
\hline Sanlam & $\begin{array}{l}\text { "Start with what you hope for"- Start something } \\
\text { campaign - a way to fulfil dreams }\end{array}$ & Thinking ahead \\
\hline Discovery & $\begin{array}{l}\text { Making a difference to your life, health, wealth \& } \\
\text { vitality }\end{array}$ & \\
\hline Hollard & Service the customer & We get you \\
\hline Outsurance & Savings and lowest price & You always get something out \\
\hline Frank & Honest, straight talking, simple affordable insurance & Life Investment made simple \\
\hline 1 Life & New generation insurance & \\
\hline PPS & Exclusive & For professionals \\
\hline
\end{tabular}

Source: Company documents

Exhibit 3: Reputation drivers \& messages in 2011

\section{Products and services}

Key message 1: You're only buying cover you need

Life assurance products today come in three basic packages (give or take a few optional extras) - Dread disease; Disability and Death. Most people get a Rand amount of cover for each with the product packaged to include many features automatically. BrightRock's breakthrough product technology is different. It allows you to identify and understand each of your financial needs if you got sick, got hurt or died; and allows us to exactly match your cover to those specific needs.

Key message 2: Your cover stays relevant

When your needs change (and they will, because that's what they do) - then so can your BrightRock cover. Which means your cover works better for you and it's more cost-efficient, because you pay only for what you need.

Key message 3: Your premiums stay affordable

The industry norm is age-rated plans, which offer you big discounts at the start only to go up sharply as you grow older. This means many people may not be able to afford their cover when they're most likely to need it. We've structured our premiums to be competitive on day one, but also to grow affordably over time. So you're more likely to be able to keep your cover.

Key message 4: You get certainty about claims

When it comes to claims, we've made sure our benefits are better than - or at the very least, as good as the best in the market. And we've written everything in everyday language, to make it easier for you to know when you can claim and how much we'll pay.

\section{Innovation}

Key message: Our product starts with you - that's a first 
BrightRock's approach of delivering an individual product that exactly matches your needs and then changes with your needs over time, is a first - no one else has ever built life insurance cover this way.

\section{Workplace}

Key message 1: Everyone contributes...

Our high-performance culture encourages and rewards individual effort, but we believe in the power of the collective effort. We believe in getting diverse inputs from various areas of our business (and elsewhere), debating the options and delivering the best solution through consensus-decisions and individual talent and effort.

Key message 2: ... and everyone benefits

And that is why we're also building a unique model to offer all our employees a share in the company's profits.

\section{Governance}

Key message: Doing things right is in our DNA

We're a new player in an old industry, where governments have recently had to intervene to ensure greater accountability and disclosure. Because we're building our business from the start with our stakeholders central to all we do, we've got no legacy issues to address. Doing things right is part of our DNA.

\section{Citizenship}

Key message: We debunk the insurance industry gumpf

Life assurance has a reputation for being opaque and complex, and full of fine print. Consumers find it hard to find information, and even harder to make informed decisions. BrightRock wants to do things differently. We want to educate consumers about our industry and its products - so whether you're a BrightRock client or not, you can rely on us to debunk the gumpf.

\section{Leadership}

Key message 1: We're the active ingredient for positive change

We drive the positive in everything we do. In every interaction - with individuals, our industry and broader society - we want to be the active ingredient that brings about a better result.

Key message 2: We have experienced leaders

BrightRock's four founders share extensive financial services experience, a complementary skills-set and an entrepreneurial vision. In their chairman, Miles Japhet, they have the backing of a respected insurance entrepreneur.

\section{Performance}

Key message 1: we have financial muscle

We're a start-up, but we've got plenty of financial muscle. We have enough seed-capital through our shareholder, Lombard, to grow our business to profitability. And our long-term reinsurance contract with Hannover Re, a leading international reinsurer, means we will always be able to pay claims.

Key message 2: We'll reach high-end consumers through financial advisers

We'll offer our needs-based products to high-end consumers in South Africa. We'll reach these consumers through an entrepreneurial, high-advice distribution model - led by highly experienced financial services sales executives. We'll distribute our products through an elite group of 1500 independent financial advisers nationally.

Key message 3: We'll target other markets in the medium term

We believe we can easily adapt our product technology to other target markets. We intend exploring these 
growth opportunities in the medium term.

Source: Company documents

Exhibit 4: Distribution and sales process - in 2012 launch presentation

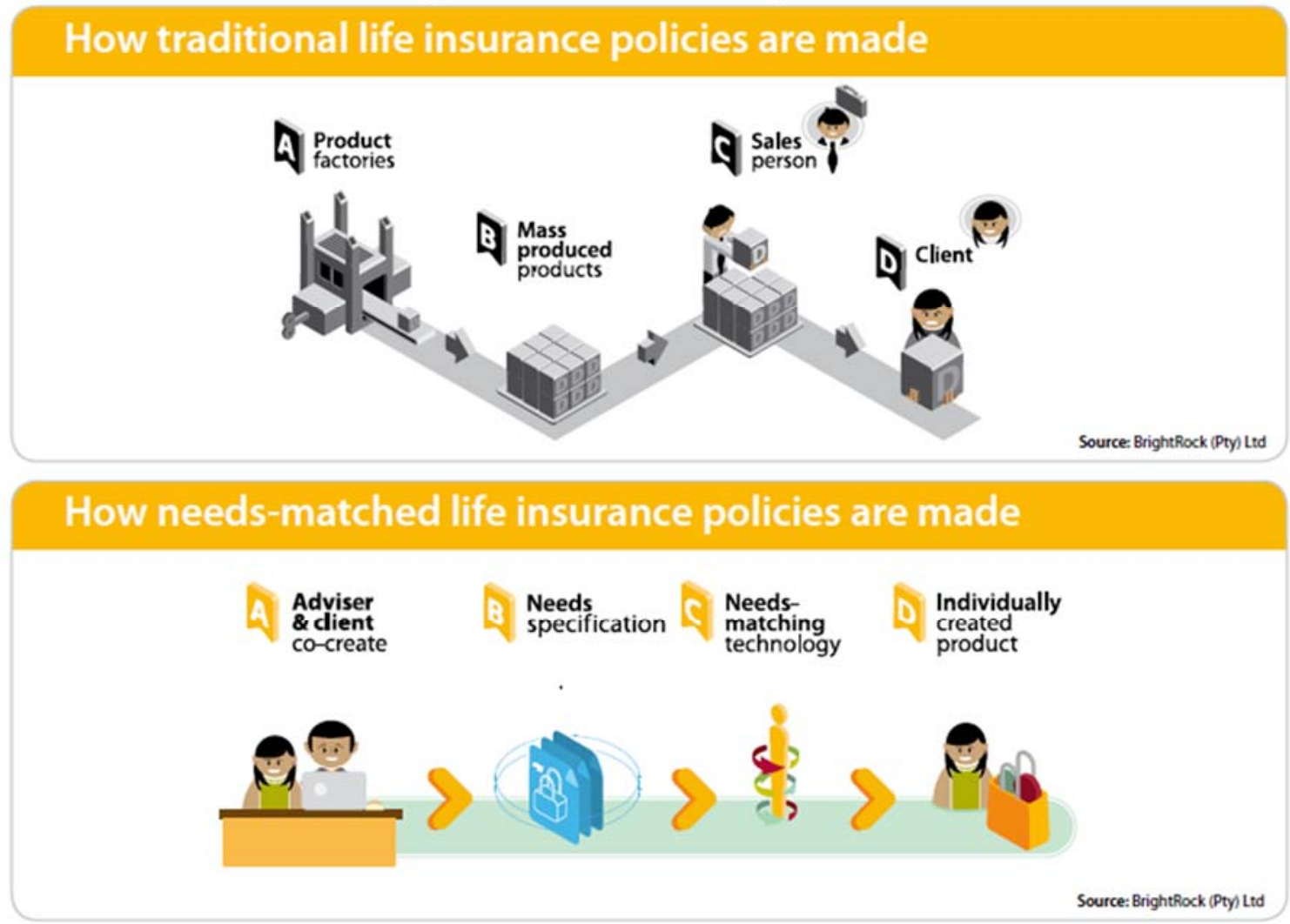

Source: Company documents 
Exhibit 5: Quoting structure - at time of launch in 2012

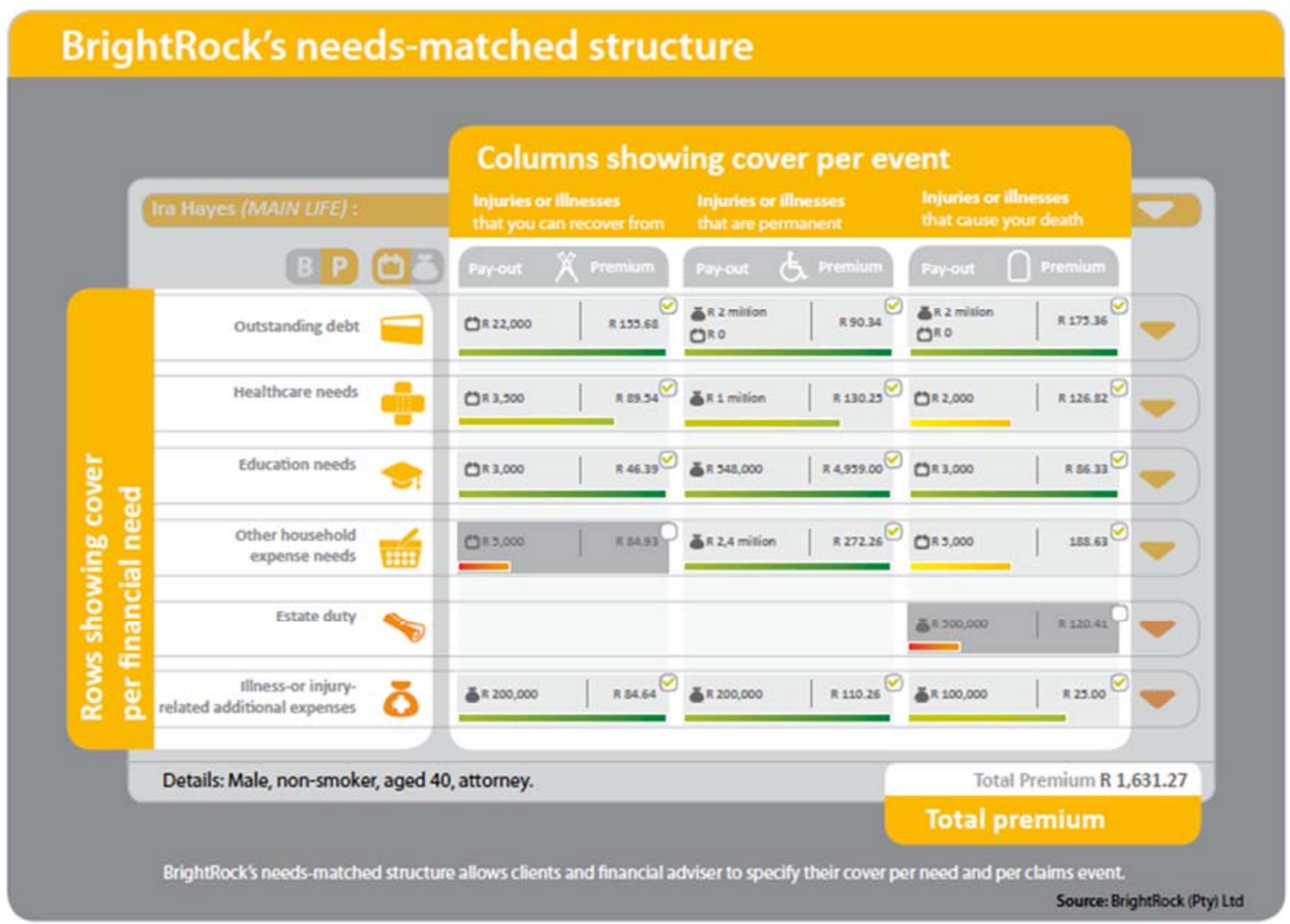

Source: Company documents

Exhibit 6: Needs over time - as explained in 2012 launch presentation

\section{Your needs change over time}

Your cover grows and changes with your needs throughout your life.

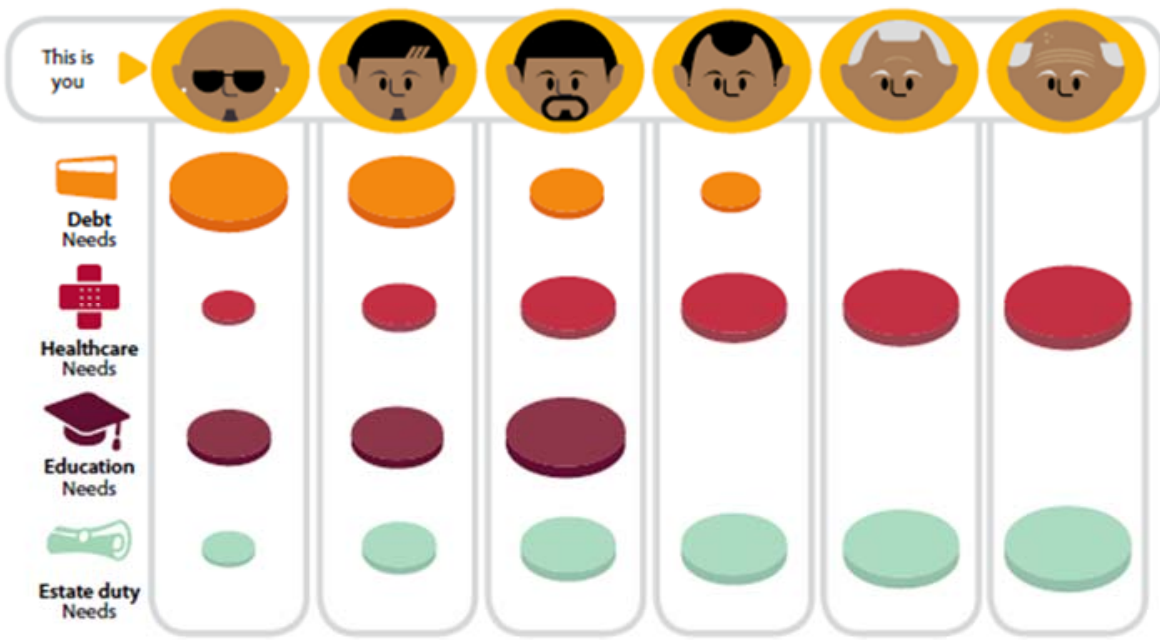

Once your bond is paid off and your children graduate, your education and debt needs will fall away - and so will your cover for those needs. But your healthcare and estate duty needs - and cover for it - will grow steadily over your lifetime. 
Exhibit 7: Launch communication schedule

\begin{tabular}{|c|c|c|c|c|c|}
\hline Date & Name & Description & Media & Market & Link \\
\hline April 2012 & $\begin{array}{l}\text { Product } \\
\text { launch }\end{array}$ & Change AV & $\begin{array}{l}\text { Presentation } \\
\text { AV \& TV }\end{array}$ & Distribution & $\begin{array}{l}\text { https://www.youtube.com/wat } \\
\text { ch?v=6bH9opQttRI }\end{array}$ \\
\hline June 2012 & Product ads & 3x print ads & Print & Consumer & \\
\hline June 2012 & $\begin{array}{l}3 \text { reasons } \\
\text { why }\end{array}$ & Website & $\begin{array}{l}\text { BrightRock } \\
\text { website }\end{array}$ & Consumer & www.brightrock.co.za \\
\hline June 2012 & $\begin{array}{l}\text { Action } \\
\text { figures }\end{array}$ & $\begin{array}{l}30 \text { second } \\
\text { radio ads }\end{array}$ & Radio & Consumer & $\begin{array}{l}\text { https://soundcloud.com/brightr } \\
\text { ock/brightrock-action-figures- } \\
\text { ad }\end{array}$ \\
\hline June 2012 & $\begin{array}{l}\text { Change } \\
\text { banners }\end{array}$ & Web ads & Online & Consumer & \\
\hline $\begin{array}{l}\text { December } \\
2012\end{array}$ & Skyfall & Activation & $\begin{array}{l}\text { Cinema/ } \\
\text { online }\end{array}$ & Consumer & $\begin{array}{l}\text { https://www.youtube.com/wat } \\
\text { ch?v= ZX2VQcyBqc }\end{array}$ \\
\hline $\begin{array}{l}\text { February } \\
2013\end{array}$ & $\begin{array}{l}\text { Brutal } \\
\text { benefits }\end{array}$ & 3x print ads & Print & Distribution & \\
\hline $\begin{array}{l}\text { February } \\
2013\end{array}$ & $\begin{array}{l}\text { Fatherhood } \\
\text { (English \& } \\
\text { Afrikaans) }\end{array}$ & $\begin{array}{l}30 \text { second } \\
\text { radio ads }\end{array}$ & Radio & Consumer & $\begin{array}{l}\text { https://soundcloud.com/brightr } \\
\text { ock/brightrocks-fatherhood-ad }\end{array}$ \\
\hline $\begin{array}{l}\text { February } \\
2013\end{array}$ & Change song & $\begin{array}{l}30 \quad \text { second } \\
\text { radio ads }\end{array}$ & Radio & Consumer & $\begin{array}{l}\text { https://www.youtube.com/wat } \\
\text { ch?v=6j_sZj30diQ }\end{array}$ \\
\hline $\begin{array}{l}\text { February } \\
2013\end{array}$ & $\begin{array}{l}\text { 5FM } \\
\text { comedy } \\
\text { clips }\end{array}$ & Sponsorship & Radio & Consumer & $\begin{array}{l}\text { https://www.youtube.com/wat } \\
\text { ch?v=L7p29WMhETI }\end{array}$ \\
\hline May 2013 & Lettuce & Video & Online & $\begin{array}{l}\text { Consumer/ } \\
\text { Distribution }\end{array}$ & $\begin{array}{l}\text { https://www.youtube.com/wat } \\
\text { ch?v=HXYYHSLMrss }\end{array}$ \\
\hline May 2013 & $\begin{array}{l}\text { Change } \\
\text { story }\end{array}$ & $\begin{array}{l}\text { Children's } \\
\text { book }\end{array}$ & Print & Internal & $\begin{array}{l}\text { http://bookshelf.brightrock.co. } \\
\text { za/StoryBook/ }\end{array}$ \\
\hline $\begin{array}{l}\text { March } \\
2013 \\
\end{array}$ & $\begin{array}{l}\text { You change } \\
\text { our ad }\end{array}$ & Competition & $\begin{array}{l}\text { Radio/ } \\
\text { online }\end{array}$ & Consumer & $\begin{array}{l}\text { https://www.youtube.com/wat } \\
\text { ch?v=tB4ozyNvqoI }\end{array}$ \\
\hline $\begin{array}{l}\text { August } \\
2013\end{array}$ & Comet & $\begin{array}{l}\text { Digital } \\
\text { publication }\end{array}$ & Online & $\begin{array}{l}\text { Consumer/ } \\
\text { Distribution/ } \\
\text { Internal }\end{array}$ & $\begin{array}{l}\text { http://thecomet.brightrock.co.z } \\
\text { a/Issue06/ }\end{array}$ \\
\hline $\begin{array}{l}\text { September } \\
2013\end{array}$ & Puberty & $\begin{array}{l}20 \text { second } \\
\text { advert }\end{array}$ & TV & Consumer & $\begin{array}{l}\text { https://www.youtube.com/wat } \\
\text { ch?v=y1tsnSy-42U }\end{array}$ \\
\hline $\begin{array}{l}\text { September } \\
2013\end{array}$ & Homeowner & $\begin{array}{l}30 \quad \text { second } \\
\text { radio ads }\end{array}$ & Radio & Consumer & $\begin{array}{l}\text { https://soundcloud.com/brightr } \\
\text { ock/home-owner }\end{array}$ \\
\hline $\begin{array}{l}\text { September } \\
2013\end{array}$ & Life changes & $\begin{array}{l}30 \text { second } \\
\text { animation }\end{array}$ & Digital & All & $\begin{array}{l}\text { https://www.youtube.com/wat } \\
\text { ch?v=5I5br46bipo }\end{array}$ \\
\hline $\begin{array}{l}\text { November } \\
2013\end{array}$ & $\begin{array}{l}\text { Change } \\
\text { game }\end{array}$ & $\begin{array}{l}\text { Facebook } \\
\text { competition }\end{array}$ & Online & Consumer & \\
\hline $\begin{array}{l}\text { November } \\
2013\end{array}$ & $\begin{array}{l}\text { Change } \\
\text { happens }\end{array}$ & $\begin{array}{l}\text { Comedy } \\
\text { night }\end{array}$ & Live event & $\begin{array}{l}\text { Internal/ } \\
\text { Distribution }\end{array}$ & $\begin{array}{l}\text { https://www.youtube.com/wat } \\
\text { ch?v=YIOLuB5wdak }\end{array}$ \\
\hline $\begin{array}{l}\text { February } \\
2014\end{array}$ & $\begin{array}{l}\text { Change } \\
\text { letter }\end{array}$ & $\begin{array}{l}\text { Online } \\
\text { content }\end{array}$ & Online & Consumer & $\begin{array}{l}\text { https://www.youtube.com/wat } \\
\text { ch?v=EejJ17C27C4 }\end{array}$ \\
\hline $\begin{array}{l}\text { February } \\
2014\end{array}$ & Change song & $\begin{array}{l}\text { Online } \\
\text { content }\end{array}$ & Online & Consumer & $\begin{array}{l}\text { https://www.youtube.com/wat } \\
\text { ch?v=bEWIwx mugA }\end{array}$ \\
\hline May 2014 & Iris sessions & $\begin{array}{l}\text { Online } \\
\text { content }\end{array}$ & Online & Consumer & $\begin{array}{l}\text { https://www.youtube.com/wat } \\
\text { ch?v=MjBmCgJPaR8 }\end{array}$ \\
\hline June 2014 & $\begin{array}{l}\text { Change } \\
\text { letter ad }\end{array}$ & $\begin{array}{l}60 \text { second } \\
\mathrm{TV} \text { ad }\end{array}$ & TV & Consumer & $\begin{array}{l}\text { https://www.youtube.com/wat } \\
\text { ch?v=UptJBPTD9hM }\end{array}$ \\
\hline June 2014 & $\begin{array}{l}\text { Dave’s Big } \\
\text { Break }\end{array}$ & $33 x$ content & $\begin{array}{l}\mathrm{TV} / \\
\text { Online/ } \\
\text { radio }\end{array}$ & Consumer & $\begin{array}{l}\text { https://www.youtube.com/wat } \\
\text { ch?v=ozHfYfaMLOY }\end{array}$ \\
\hline
\end{tabular}




\begin{tabular}{|l|l|}
\hline \multicolumn{2}{|l|}{ BrightRock online channels } \\
\hline Corporate website & www.brightrock.co.za \\
\hline Blog & www.ChangeExchange.co.za \\
\hline Facebook & BrightRock - Love Change \\
\hline Twitter & @BrightRockZA \\
\hline LinkedIn & BrightRockZA \\
\hline YouTube & BrightRock TV \\
\hline
\end{tabular}

Source: Company documents

Exhibit 8: Selection of initial Change Agents

Sam Wilson: "Sam works in the fast-changing world of social media and lives in Cape Town with her husband Andreas and teenage sons, Josef and Benjamin. She is an 'expert' in the art of 'weird parenting'."

Paul Kerton: "Paul is a Yorkshire born writer, editor and publisher. Dad to Saskia and Sabina, he is the author of FabDad, a book aimed at first fathers who want to be great dads without loosing who they are in the process."

Kagiso Msimango: "Kagiso is passionate about the personal development of women. Since starting The Goddess Academy in 2006, she has been supporting and inspiring women to create lives filled with pleasure, passion and purpose."

Alan Knott-Craig Jr: Alan is a CA who moved into the world of technology with an unquenchable thirst for telecommunications. He has co-founded or funded 17 companies in the telecoms, tech and media sector, including his latest venture, the free WiFi organisation, Project Isizwe."

Teboho Monyamane: "Teboho is a Johannesburg-based clinical psychologist in private practice. She's always been fascinated by people and the inter-relationships between them.”

Source: Company documents 
Exhibit 9: BrightRock Consumer Marketing Model

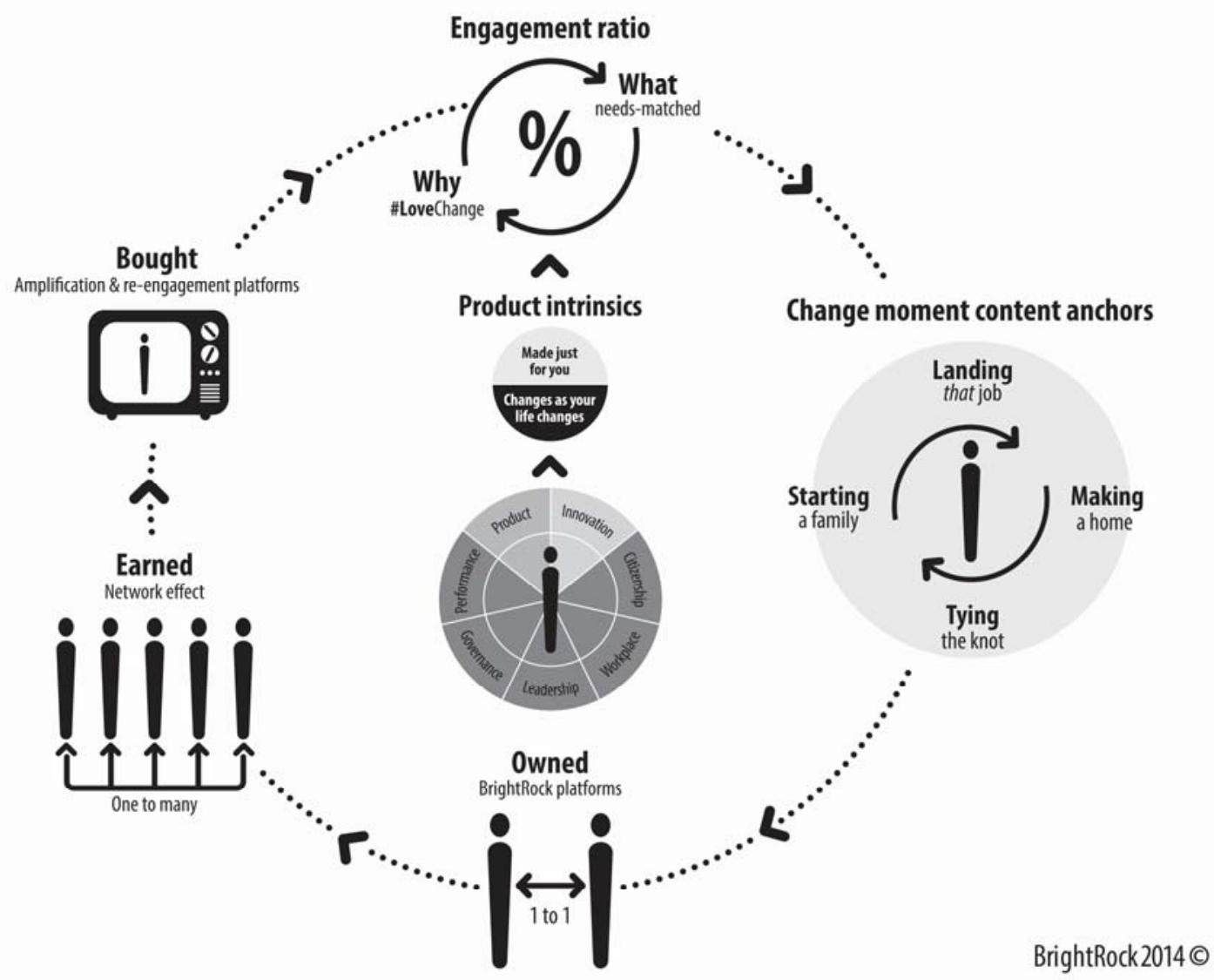

Source: Company documents 
${ }^{1}$ PricewaterhouseCoopers (2010). Strategic and emerging issues in South African insurance.

${ }^{2}$ MarketLine, Life Insurance in South Africa, January 2015 (Reference code 0044-0976), London

${ }^{3}$ BMI Research, Industry Forecast - South Africa - Q3 2015.

${ }^{4}$ True South Actuaries and Consultants (2013). The South African insurance gap in 2013. Retrieved from https://www.asisa.org.za/asisadocs/research-and-publications/insurance-gap2013/True\%20South\%202013\%20Gap\%20Study\%20-\%20Final\%20Report.pdf.

${ }^{5}$ MarketLine, Life Insurance in South Africa, January 2015 (Reference code 0044-0976), London

${ }^{6}$ KPMG (2011). The South African Insurance Industry Survey 2011

${ }^{7}$ PricewaterhouseCoopers (2010). Strategic and emerging issues in South African insurance.

${ }^{8}$ Personal interview with Suzanne Stevens, 23 March 2015

${ }^{9}$ BrightRock Board Report: Marketing Division, November 2011

${ }^{10}$ Fombrun, C. J., Ponzi, L. J., \& Newburry, W. (2015). Stakeholder Tracking and Analysis: The RepTrack System for Measuring Corporate Reputation. Corporate Reputation Review, 18(1), 3-24.

${ }^{11}$ Vlok, K. (2013, November 12). Sustaining sales growth, and its unintended consequences. Cover. Retrieved from http://www.cover.co.za/financial-planning/sustaining-sales-growth-and-its-unintendedconsequences.

${ }^{12}$ Louw, L., \& van Tonder, D. (2008). Best business practices in the South African independent financial advisor's practice: An exploratory study. Academy of Banking Studies Journal, 7(2), 59-86.

${ }^{13}$ BrightRock Media Relations Department (2013). BrightRock Life Insurance announces the winner of the company's "You change our ad" initiative. Retrieved from http://www.sbwire.com/press-

releases/brightrock-life-insurance-announces-the-winner-of-the-companies-you-change-our-ad-initiative251305.htm. 